\title{
miR-155-3p Drives the Development of Autoimmune Demyelination by Regulation of Heat Shock Protein 40
}

\author{
Marcin P. Mycko, ${ }^{\star}$ Maria Cichalewska, ${ }^{\star}$ Hanna Cwiklinska, and Krzysztof W. Selmaj \\ Department of Neurology, Laboratory of Neuroimmunology, Medical University of Lodz, 90-153 Lodz, Poland
}

microRNA-155 (miR-155) plays an important role in posttranscriptional gene regulation of the immune system. We and others have described miR-155 upregulation in Thelper cells (Th) during the development of experimental autoimmune encephalomyelitis (EAE), an animal model of multiple sclerosis. We have shown that mice in which the miR-155 host gene (MIR155HG) has been deactivated are resistant to EAE. MIR155HG produces two different miRNA strands, miR-155-5p and miR-155-3p, and miR-155-5p has been considered the only functional miR-155 form. Surprisingly, we found that miR-155-3p is also strongly upregulated in Th cells infiltrating the brain in EAE. Functional manipulation of miR-155-3p expression revealed its particular role in regulation of Th17 development. The search for miRNA-155-3p target genes highlighted transcripts of two heat shock protein 40 genes, Dnaja2 and Dnajb1. These two genes negatively regulated Th17 differentiation, leading to decreased EAE. Therefore, our findings provide new insights into a previously unknown mechanism by which miR-155-3p controls Th17 cell differentiation and autoimmune demyelination.

Key words: autoimmune demyelination; experimental autoimmune encephalomyelitis; heat shock proteins; microRNA; multiple sclerosis; T helper cells

\section{Significance Statement}

Multiple sclerosis (MS) is brain-specific autoimmune disease mediated by T helper (Th) cells autoreactive to myelin. The mechanisms leading to MS are not fully understood and microRNAs (miRNAs) emerge as important regulators of the process. We report that, in an MS murine model of experimental autoimmune encephalomyelitis, miR-155 controls Th cell function by an unusual mechanism involving a rare form, miR-155-3p. miR-155-3p is specifically found in brain-infiltrating myelin-autoreactive $\mathrm{CD} 4{ }^{+} \mathrm{T}$ cells and contributes to the development of an encephalitogenic Th17 population. miR-155-3p promotes Th17 by inhibiting two heat shock protein 40 genes, Dnaja2 and Dnajb1. Our findings indicate a unique miRNA function in the brain-infiltrating Th cells and suggest Dnaja2 and Dnajb1 as targets for intervention in autoimmune demyelination.

\section{Introduction}

Multiple sclerosis (MS) is an organ-specific autoimmune disease manifested by chronic inflammatory demyelination of the CNS.

\footnotetext{
Received July 28, 2015; revised Sept. 30, 2015; accepted Sept. 30, 2015.

Author contributions: M.P.M. and K.W.S. designed research; M.P.M., M.C., and H.C. performed research; M.P.M., M.C., and K.W.S. analyzed data; M.P.M. and K.W.S. wrote the paper.

This work was supported by the National Science Centre Poland (MAESTRO 2012/04/A/NZ6/00423 to K.W.S.), the National Science Centre Poland (Grant OPUS UMO-2013/11/B/NZ6/02055 to H.C.), Polish-Swiss Research Programme Grant 007/2012 (M.P.M.), the National Science Centre Poland (Grant SONATA to M.C.), the Medical University of Lodz Grant for Young (502-03/1-033-01/502-14-223 to M.C.), and the National Center for Research and Development (Grant ERA.NET-RUS/16/2011 to M.P.M.). miR-155-deficient mice were kindly provided by A. Bradley (The Wellcome Trust Sanger Institute, Cambridge, UK). We thank M. Jurynczyk (Medical University of Lodz, Poland) for providing small density murine expression arrays and C.F. Brosnan (Albert Einstein College of Medicine, Bronx, NY) for discussions and for editing the manuscript.

The authors declare no competing financial interests.

*M.P.M. and M.C. contributed equally to this work and are cofirst authors of this paper.

Correspondence should be addressed to Krzysztof W. Selmaj, Department of Neurology, Laboratory of Neuroimmunology, Medical University of Lodz, Kopcinskiego 22, 90-153 Lodz, Poland. E-mail: kselmaj@afazja.am.lodz.pl. DOI:10.1523/JNEUROSCI.2830-15.2015

Copyright $\odot 2015$ the authors $\quad 0270-6474 / 15 / 3516504-12 \$ 15.00 / 0$
}

$\mathrm{CD} 4{ }^{+} \mathrm{T}$-cell-mediated autoimmunity against a putative myelin autoantigen has long been accepted as one of the most important aspects of MS pathogenesis, especially for the early initiation of disease (Sospedra and Martin, 2005). These findings have been supported by research using experimental autoimmune encephalomyelitis (EAE), an animal model of MS. Thelper type 1 (Th1) cells, characterized by the expression of the transcription factor T-bet and production of interferon-gamma (IFNg), have been considered the major effector Th cells that mediate autoimmune demyelination (Hafler, 2004). More recently, another subset of Th cells, Th17, characterized by expression of the transcription factors retinoic acid receptor-related orphan receptor $\alpha$ and gamma $t$ (ROR- $\alpha$ and ROR-yt) and the production of interleukin-17 (IL-17), has been found to be pivotal for the propagation of autoimmune demyelination (Bettelli et al., 2008). Mice with impaired numbers or function of Th17 cells, particularly mice deficient in the cytokines IL- 6 or IL-23, are largely resistant to EAE (Eugster et al., 1998; Cua et al., 2003; Bettelli et al., 2006). However, the precise mechanisms that govern the de- 
velopment and function of pathogenic Th17 cells resulting in autoimmune demyelination are still unclear (Lee et al., 2014). Therefore, Th17-targeting therapeutic approaches for MS are still far from being established.

MicroRNAs (miRNAs) operate as short, noncoding RNA molecules that are processed from larger transcripts of nonclassical genes by Drosha and Dicer nucleases (Xiao and Rajewsky, 2009). Mature miRNA biogenesis is a tightly controlled multistep process finalizing in the production of an $\sim 22$-nt-long duplex. This duplex is transferred to one of the Argonaute (Ago) proteins, where, in a process called strand selection, one miRNA strand called a passenger is supposedly discarded (Wang et al., 2009). The remaining leading strand of miRNA guides Ago-containing active RNA-induced silencing complex (RISC) to interact with the target mRNA. The mechanism of strand selection is not known, but a passenger strand might also emerge as an active miRNA. In this way, miRNA regulates gene-expression programs by reducing the translation and stability of target mRNAs (Jinek and Doudna, 2009). It has been estimated that the expression of as many as one-third of protein-coding genes may be regulated by miRNA (Selbach et al., 2008).

Many miRNAs have emerged as critical regulators of the immune system. In particular, miR-155 has been reported as a crucial player orchestrating the function of numerous acquired and native immune cell populations. The miR-155 host gene (MIR155HG) produces two different miRNA strands, miR155-5p and miR-155-3p, with miR-155-5p being the functional miR-155 form (Chiang et al., 2010). In previous studies, we identified increased miR-155 expression in T cells both in vivo an in vitro during the development of autoimmune responses (Mycko et al., 2012), and miR-155-deficient mice have been found to be resistant to the development of EAE (O'Connell et al., 2010; Murugaiyan et al., 2011). We have recently demonstrated profound changes of RISC assembly in T cells during EAE (Lewkowicz et al., 2015). In the present study, we sought to elucidate how this affects miR-155 function in Th cells during EAE. The results demonstrate that the profile of miR-155 expression is dramatically changed during EAE, with overexpression of the unusual miR155-3p product of the MIR155HG. Therefore, we have identified an EAE-specific mechanism of miR-155 expression, in particular miR-155-3p strand selection, in Th cells that contributes to the encephalitogenic potential of Th17 cells.

\section{Materials and Methods}

Mice. C57BL/6, C57BL/6-Tg(Tcra2D2,Tcrb2D2)1Kuch/J (2D2 mice) female mice were purchased from Jackson Laboratories, Rag $2 \mathrm{KO}$ mice from Taconic, and miR-155-deficient mice on a C57BL/6J background (miR-155 ${ }^{-1-}$ ) have been described previously (Rodriguez et al., 2007). All mice were maintained in our colony for the duration of the experiments. All animal protocols were approved by the Institutional Animal Care and Use Committee of the Medical University of Lodz.

Antibodies, cytokines, peptides. Fluorochrome-conjugated antibodies specific for CD3, CD4, CD8, CD11b, B220, IL-17A, IFNg, blocking antiIL-4, and anti-IFNg antibodies were purchased from BD Biosciences; $\mathrm{MOG}_{35-55}$ peptide was from Peptide 2.0; IL-6 was from PeproTech; IL-1b was from Sigma-Aldrich; and TGFb and IL-23 were from R\&D Systems.

Immunization and Th cell cultures and assays. Eight- to 12-week-old C57BL/6 mice were immunized subcutaneously over the abdominal flanks with $0.15 \mathrm{mg}$ of $\mathrm{MOG}_{35-55}$ peptide in $150 \mu \mathrm{l}$ of complete Freund's adjuvant (CFA; Sigma-Aldrich) containing $0.75 \mathrm{mg}$ of Mycobacterium tuberculosis (Difco Laboratories). Peripheral (popliteal and inguinal) lymph nodes (PLNs) or spleens were isolated and single-cell suspensions were cultured in triplicate at a density of $2 \times 10^{5}$ cells per well in $200 \mu \mathrm{l}$ U-bottomed microtiter well plates. For RNA isolation, cultured $\mathrm{CD} 4{ }^{+} \mathrm{T}$ cells were isolated by indirect magnetic sorting with a CD4 ${ }^{+} \mathrm{T}$ Cell Isolation Kit II (Miltenyi Biotech).

Th cell cultures. For cell culture stimulation, single-cell suspensions of freshly isolated splenocytes or sorted T cells from C57BL/6 were cultured for $24 \mathrm{~h}$ in IMDM-based cell culture medium in triplicate at a density of $2 \times 10^{5}$ cells per well in $200 \mu \mathrm{l}$ U-bottomed microtiter well plates with plate-bound anti-CD3 and anti-CD28 (both at $2 \mu \mathrm{g} / \mathrm{ml}$ ). CD4 ${ }^{+} \mathrm{T}$ cells were isolated either directly from splenocytes or from cell cultures by indirect magnetic sorting with a CD4 ${ }^{+} \mathrm{T}$ Cell Isolation Kit II or with a $\mathrm{CD} 4{ }^{+} \mathrm{CD} 62 \mathrm{~L}^{+} \mathrm{T}$ Cell Isolation Kit II (Miltenyi Biotech).

Immunization and stimulation of Th cell cultures with antigen. Eight- to 12-week-old C57BL/6 mice were immunized subcutaneously over the abdominal flanks with $0.15 \mathrm{mg}$ of $\mathrm{MOG}_{35-55}$ peptide in $150 \mu \mathrm{l}$ of CFA (Sigma-Aldrich) containing $0.75 \mathrm{mg}$ of $M$. tuberculosis (Difco Laboratories). Splenocytes in single-cell suspensions were cultured in triplicate as described above, followed by $72 \mathrm{~h}$ stimulation with $\mathrm{MOG}_{35-55}$ antigen.

Th subpopulations: in vitro differentiation. Th17 and Th0 in vitro differentiation was performed from splenic naive $\mathrm{CD} 4{ }^{+} \mathrm{T}$ cells that had been stimulated with plate-bound anti-CD3 $(5 \mu \mathrm{g} / \mathrm{ml})$ and anti-CD28 $(10 \mu \mathrm{g} / \mathrm{ml})$ and polarized for $6 \mathrm{~d}$ with the following: TGFb $(2 \mathrm{ng} / \mathrm{ml})$, IL-1b (20 ng/ml), IL-23 $(20 \mathrm{ng} / \mathrm{ml})$ in the presence of anti-IL-4 (10 $\mu \mathrm{g} / \mathrm{ml})$ and anti-IFNg $(10 \mu \mathrm{g} / \mathrm{ml})$ and with the addition of $40 \mathrm{~mm} \mathrm{NaCl}$ for Th17; TGFb $(10 \mathrm{ng} / \mathrm{ml})$ and IL-2 $(100 \mathrm{U} / \mathrm{ml})$ in the presence of anti-IL-4 $(10 \mu \mathrm{g} / \mathrm{ml})$ and anti-IFNg $(10 \mu \mathrm{g} / \mathrm{ml})$. Th0 conditions were maintained by naive $\mathrm{CD} 4{ }^{+} \mathrm{T}$ cells cultured in the presence of anti-IL-4 $(10 \mu \mathrm{g} / \mathrm{ml})$ and anti-IFNg $(10 \mu \mathrm{g} / \mathrm{ml})$. After $6 \mathrm{~d}$ of culture in Th17 or Th0 polarizing conditions, cells were assayed for cytokine production by intracellular flow cytometry.

Transfections of antagomirs against miR-155-5p, miR-155-3p, mimics for miR-155-5p, miR-155-3p, and expression plasmids for Dnaja2 and Dnajb1. 5'-Fluorescein labeled antagomirs against miR-155-5p, miR-155-3p and control $5^{\prime}$-fluorescein labeled antagomir (scrambled oligonucleotide) were purchased from Exiqon. Mimics for miR-155-5p, miR-155-3p, and control mimic (scrambled oligonucleotide) were purchased from Life Technologies. Expression plasmids pEZ-M61 for Dnaja2 and Dnajb1 (coexpressing GFP) and control plasmid pEZ-M61 (with GFP expression) were purchased from GeneCopoeia. Th cells have been transfected by electroporation with $4 \mathrm{D}$-Nucleofector (Lonza) according to the manufacturer's instructions. The effectiveness of transfection was monitored by the presence of the fluorescein-positive cells in flow cytometry analysis.

Extraction of RNA and mRNA expression analysis. Extraction of total RNA was performed using a mirVana kit (Ambion). For quantitative analysis of RNA expression, we performed real-time qRT-PCR with TaqMan probes (Life Technologies) using a 7500 Real Time PCR System (Applied Biosystems). mRNA expression data were normalized to that of the polymerase (RNA) II (DNA directed) polypeptide A (POLR2A). Expression was evaluated by the comparative cycling threshold $\left(\Delta \Delta \mathrm{C}_{\mathrm{T}}\right)$ method. For small density expression arrays, qRT-PCR was performed with the 96 well plates containing a series of different TaqMan probes (Life Technologies). The gene expression analysis of the small density arrays and heat maps were grouped using hierarchical clustering using DataAssist software (Life Technologies). All array data have been deposited to the Gene Expression Omnibus (http://www.ncbi.nlm.nih.gov/ geo/) under accession number GSE65488. miRNA quantification of the probes has been obtained with digital qRT-PCR using a specific miRNA TaqMan gene expression probes (Life Technologies) and a QX200 Droplet Digital PCR System (Bio-Rad) according to the manufacturer's instructions. The results have been expressed as miRNA copies number per cell.

Luciferase reporter assay for target validation. HEK-293 cells were transfected with pEZX-MT01 vectors containing either wild-type firefly luciferase or firefly luciferase with either Dnaja2 or Dnajb1 3' UTR (GeneCopoeia) and with $50 \mathrm{~nm}$ concentrations of mimic miR-155-5p, mimic miR-155-3p, or negative-control oligonucleotide (Thermo Scientific). The cells were lysed and luciferase activity was measured $24 \mathrm{~h}$ after transfection using MicroBeta ${ }^{2}$ LumiJet (PerkinElmer).

Isolation of brain-infiltrating cells. Mice were perfused intracardially with PBS before dissection of the brain, which was subsequently homog- 
enized and brain-infiltrating mononuclear cells were isolated using 37\%/ $70 \%$ Percoll gradients.

Single-cell miR-155-5p and miR-155-3p expression detection. miR155-5p and miR-155-3p detection in single cells was conducted using specific Smartflare Cy5-conjugated probes (Merck Millipore) according to the manufacturer's instructions. Briefly, probes were added to a singlecell suspension in IMDM culture medium in 96 well plates at a concentration of $100 \mathrm{pm}$, followed by $16 \mathrm{~h}$ incubation at $37^{\circ} \mathrm{C}$. Subsequently, the cells were washed, surfaces stained with fluorochrome-conjugated antibodies, and analyzed with flow cytometry. Negative staining levels were determined with the miRNA Negative Scramble-Cy5 SmartFlare Probe (Merck Millipore).

Flow cytometry and cell sorting. Four- to six-color flow cytometry analysis was performed with the LSR II (Becton Dickinson) according to standard procedures. For intracellular detection of cytokine production, Th cells were stimulated with $500 \mathrm{ng} / \mathrm{ml}$ phorbol dibutyrate and 500 $\mathrm{ng} / \mathrm{ml}$ ionomycin in the presence of brefeldin A for 6 h. Detection of IL-17A- and IFNg-positive CD4 ${ }^{+} \mathrm{T}$ cells was performed by intracellular staining using a Mouse Regulatory $\mathrm{T}$ cell Staining Kit (eBioscience). I-Ab $\mathrm{MOG}_{35-55}$ Tetramer was purchased from MBL. Flow cytometry data were analyzed with FlowJo. Cell sorting was performed following a fourto six-color flow cytometry analysis with BD Aria equipment (Becton Dickinson) according to standard procedures.

Induction of EAE. Active EAE was induced by subcutaneous immunization over the abdominal flanks of 8- to 12 -week-old mice with $0.15 \mathrm{mg}$ of $\mathrm{MOG}_{35-55}$ peptide in $150 \mu \mathrm{l}$ of CFA containing $0.75 \mathrm{mg}$ of $M$. tuberculosis. In addition, $0.2 \mu \mathrm{g}$ of Pertussis toxin (Sigma-Aldrich) was injected intravenously on days 0 and 2. Mice were checked daily for body weight and signs of EAE and scored on a scale of $0-5$ as follows: 0 , no disease; 1 , weak tail or unsteady gait; 2 , hind-limb paresis; 3 , hind-limb paralysis; 4 , hind- and fore-limb paralysis; and 5, death or euthanasia for humane reasons. The cumulative EAE score has been determined as an average of the sum of the individual daily animal clinical scores over the observation period.

Transfer model of EAE in Rag2 $\mathrm{KO}$ mice. $\mathrm{MOG}_{35-55}-\mathrm{TCR}$ transgenic $\mathrm{CD} 4{ }^{+} \mathrm{T}$ cells were isolated from PLNs and spleens of unimmunized 2D2 mice and in vitro transfected with expression plasmids for Dnaja2, Dnajb1, or with a control plasmid. After $24 \mathrm{~h}$ of culture, 2D2-transgenic $\mathrm{CD} 4{ }^{+} \mathrm{T}$ cells were washed and $2 \times 10^{6}$ cells transferred intravenously into naive 10 -week-old Rag2 $\mathrm{KO}$ female mice. On the day of $\mathrm{CD}^{+}{ }^{+} \mathrm{T}$ cells transfer, active EAE was induced. Mice were observed daily for neurologic signs of EAE and scored as described above.

Western blot analysis. Cells were lysed and total lysates were resolved on SDS electrophoresis gels by standard procedures. Immunoblotting was performed with mouse primary antibodies to DNAJA2 (Santa Cruz Biotechnology), DNAJB1 (Enzo Life Sciences), and GAPDH (Millipore) and visualized by G:BOX Chemi (Syngene). Quantitative densitometric analysis was performed using the program G:BOX Chemi-XR5 (Syngene).

Statistical analysis. Results were compared using the program StatGraphics Centurion XV (StatPoint Technologies). Clinical data from mice with EAE were compared using the Mann-Whitney $U$ test. Results of proliferation and qRT-PCR were compared using the Student's $t$ test. $p<0.05$ was considered statistically significant.

\section{Results}

miR-155-5p and miR-155-3p are both present in $\mathrm{CD}^{+}{ }^{+} \mathrm{T}$ cells during EAE

We have previously identified an upregulation of miR-155 in T cells during the development of the $\mathrm{CD} 4^{+} \mathrm{T}$-cell response toward a myelin antigen (Mycko et al., 2012). To confirm the in vivo significance of miR-155 for the development of EAE, we actively induced the disease in mice with an inactivated MIR155HG gene (miR-155-deficient mice) with MOG peptide ${ }_{35-55}\left(\mathrm{MOG}_{35-55}\right)$. We found that, whereas miR-155-sufficient animals developed a typical monophasic disease followed by an incomplete remission, miR-155-deficient animals were significantly protected from EAE development, demonstrating a delayed disease onset, decreased disease maximum severity, and complete recovery from clinical signs by day 60 after disease induction (Fig. $1 A, B$ ). These findings confirm the previous reports that miR-155-deficient mice are resistant to EAE induction (O'Connell et al., 2010; Murugaiyan et al., 2011).

To understand the mechanism of EAE regulation by miRNA-155, we analyzed the expression of its two strands, miR-155-5p and miR-155-3p, in the major immune populations driving EAE, Th cells (CD4 ${ }^{+} \mathrm{T}$ cells) and monocytes/ microglia $\left(\mathrm{CD} 11 \mathrm{~b}^{+}\right.$cells). We isolated Th cells and CD11b ${ }^{+}$ cells from both spleens and brains of EAE animals on day 13 (day of disease onset) and day 27 (clinical peak of disease). As a control, we isolated similar cell populations from spleens of naive animals. The cell-sorting strategy used for EAE braininfiltrating cells is shown in Figure $1 C$.

An analysis of miR-155-5p copy number per cell revealed its highest presence in $\mathrm{CD} 4^{+} \mathrm{T}$ cells isolated from the brain on day 13 of EAE. In the spleen, miRNA-155-5p content showed an 8 -fold increase compared with normal spleen $\mathrm{CD} 4{ }^{+} \mathrm{T}$ cells (Fig. $1 D)$. However, miR-155-3p was also readily detected in $\mathrm{CD} 4^{+} \mathrm{T}$ cells from EAE animals, but was virtually absent in $\mathrm{CD} 4{ }^{+} \mathrm{T}$ cells from control spleens $(~ \sim 0.5$ copies per cell). Interestingly, the fold increase of miR-155-3p in EAE brain CD4 ${ }^{+} \mathrm{T}$ cells versus control spleen was 8 -fold higher (68 to 8 ) than the increase of miR155-5p expression in EAE brain T cells (Fig. 1D). For CD11b ${ }^{+}$ cells, miR-155-5p was found in both brain and spleen cells, whereas miR-155-3p was practically undetected in these cells $(<1$ copy per cell; Fig. $1 E$ ). In contrast to $\mathrm{CD} 4^{+} \mathrm{T}$-cell analysis, we failed to identify a $>2$ fold increase of miR-155 presence in $\mathrm{CD}_{11} \mathrm{~b}^{+}$cells during EAE (Fig. 1D). Therefore, profiling of the miR-155 during EAE has confirmed our previous report on the profound upregulation of miR-155-5p in Th cells infiltrating the CNS during EAE (Mycko et al., 2012) and has identified miR-155-3p as being the highest upregulated MIR155HG gene product in $\mathrm{CD}^{+}{ }^{+} \mathrm{T}$ cells in brain during EAE.

\section{Brain-infiltrating myelin-autoreactive $\mathrm{CD} 4^{+} \mathrm{T}$ cells during EAE highly express miR-155-5p and miR-155-3p}

To confirm the upregulation of the both MIR155HG gene products in $\mathrm{CD} 4{ }^{+} \mathrm{T}$ cells during EAE, we investigated the expression of these miRNAs on a single-cell level by flow cytometry. We have found a strong upregulation of the miR155-5p-positive $\mathrm{CD} 4^{+} \mathrm{T}$ cells during EAE in both spleen and brain compared with control mouse spleen (Fig. 2A). Once again, more $\mathrm{CD}^{+} \mathrm{T}$ cells were positive for miR-155-3p in both spleen and brain during EAE (Fig. 2A). These findings confirm the data from the miR-155 expression analysis and indicate that miR-155-3p is more highly upregulated in $\mathrm{CD} 4^{+}$ $\mathrm{T}$ cells during EAE then miR-155-5p.

We then used I-A ${ }^{\mathrm{b}}-\mathrm{MOG}_{35-55}$ tetramer staining to specifically identify myelin-autoreactive $\mathrm{CD} 4^{+} \mathrm{T}$ cells during EAE. As expected, we found this population to be upregulated in both spleen and brain during EAE, whereas these cells were practically undetectable $(<0.01 \%)$ in unimmunized mice (Fig. $2 B)$. Importantly, $\mathrm{MOG}_{35-55}$-reactive $\mathrm{CD} 4^{+} \mathrm{T}$ cells were enriched with regard to both miR-155 strands, miR-155-5p and miR-155-3p, compared with tetramer-negative $\mathrm{CD} 4{ }^{+} \mathrm{T}$ cells (Fig. 2C). In particular, EAE brain-infiltrating $\mathrm{MOG}_{35-55}$-reactive $\mathrm{CD} 4^{+} \mathrm{T}$ cells were very highly positive for the presence of miR-155-3p (55\%) and miR$155-5 \mathrm{p}(42 \%)$. Therefore, we have identified that more than half of the EAE brain-infiltrating myelin-reactive $\mathrm{CD}^{+}{ }^{+} \mathrm{T}$ cells express miR-155-3p. 
A

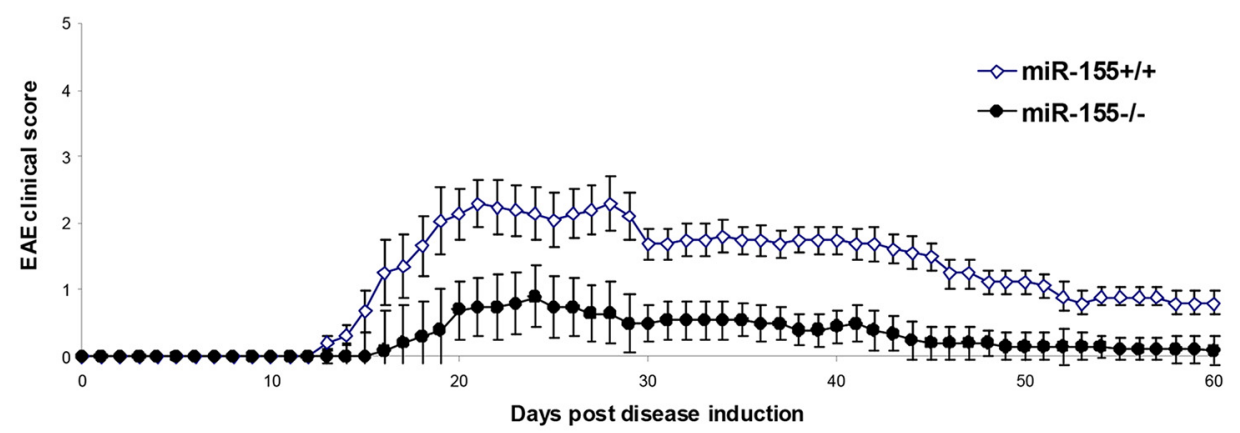

B

\begin{tabular}{c|c|c|c|c}
\hline Mice & $\begin{array}{c}\text { EAE } \\
\text { incidence }\end{array}$ & $\begin{array}{c}\text { Cumulative EAE } \\
\text { score }\end{array}$ & $\begin{array}{c}\text { Maximum EAE } \\
\text { score }\end{array}$ & $\begin{array}{c}\text { Day of EAE } \\
\text { onset }\end{array}$ \\
\hline miR-155 +/+ & $10 / 10$ & $71 \pm 19$ & $3.3 \pm 1.5$ & $16 \pm 2.9$ \\
\hline miR-155 $-/-$ & $8 / 10$ & $17 \pm 11^{*}$ & $1.5 \pm 1.2^{*}$ & $17 \pm 1.6$ \\
\hline
\end{tabular}

C

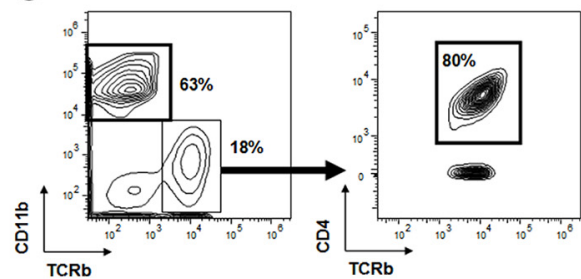

D

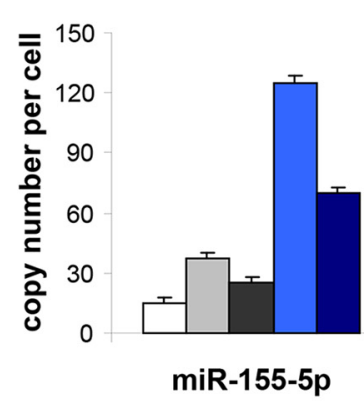

E

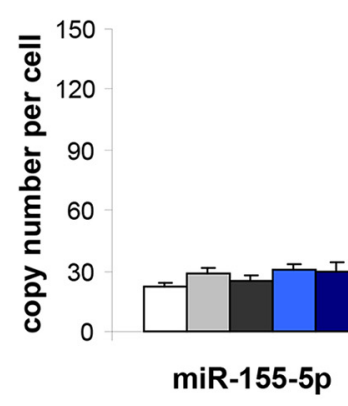

\section{CD4+ $T$ cell}

$\square$ Spleen control

$\square$ Spleen EAE (d13)

$\square$ Spleen EAE (d21)

$\square$ Brain EAE (d13)

- Brain EAE (d21)

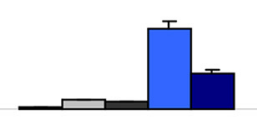

miR-155-3p

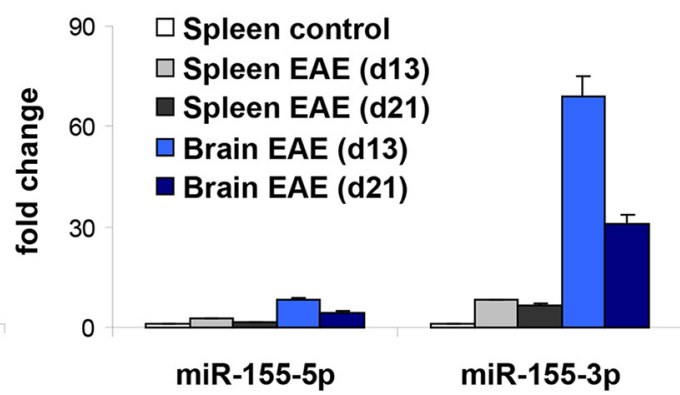

\section{CD11b+ cell}
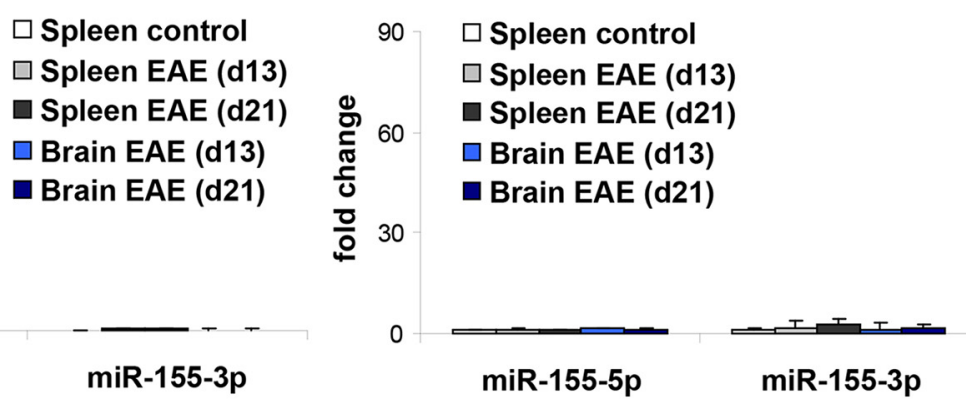

Figure 1. miR-155 expression in the CNS-infiltrating cells during EAE. A, miR-155-deficient (miR-155 ${ }^{-/-}$) and miR-155-sufficient (miR-155 $5^{+/+}$) mice have been induced for EAE with $M O G_{35-55}$. Clinical scores of the mice are presented as mean \pm SEM. Ten mice per group were used. Asterisks indicate significant differences (Mann-Whitney $U$ test; ${ }^{*} p<0.01$ ). $\boldsymbol{B}$, Summary of EAE

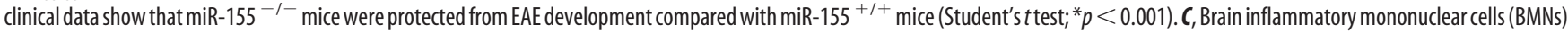
peak stage of EAE (day 27) were sorted by flow cytometry into $C D 4^{+} T$ cells $\left(C D 4^{+} \mathrm{TCRb}^{+} \mathrm{CD} 11 \mathrm{~b}^{-}\right)$and macrophages/microglia $\left(\mathrm{CD} 11 \mathrm{~b}^{+} \mathrm{TCRb}{ }^{-}\right)$subsets. $\boldsymbol{D}-\boldsymbol{E}$, Subsequently, these fractions, as well as parallel CD4 ${ }^{+} \mathrm{T}$ cell and CD11 $\mathrm{b}^{+} \mathrm{TCRb}^{-}$macrophages from spleen, were analyzed for levels of miR-155-5p and miR-155-3p by digital qRT-PCR. Representative results of either copy number per cell (left) or fold upregulation compared with respective normal mice splenic population expression from three independent experiments are shown, each of $4-5$ brains and $4-5$ spleens.

miR-155-3p presence in $\mathrm{CD} 4{ }^{+} \mathrm{T}$ cells promotes

Th17 development

To understand the functional significance of both miR-155 strands in $\mathrm{CD}^{+}{ }^{+} \mathrm{T}$ cells, we isolated these cells from control spleens and transfected them with a mimic for miR-155-5p, a mimic for miR-155-3p, or a control oligonucleotide. Subsequently, these cells were stimulated with anti-CD3 and changes in gene expression changes analyzed were compared with expres- sion levels in unstimulated $\mathrm{CD} 4{ }^{+} \mathrm{T}$ cells (Fig. 3 ). $\mathrm{CD}^{+}{ }^{+} \mathrm{T}$ cells transfected with miR-155-5p showed upregulation of Th1 marker genes Tbx21 and Ifng, Th17 marker genes Rora and Ill7a, and downregulation of the Th2 marker gene Gata3. This confirms our previous data on miR-155 manipulation in $\mathrm{CD}^{+}{ }^{+} \mathrm{T}$ cells (Mycko et al., 2012), as well as previous results on the role of miR-155 in Th1, Th2, and Th17 development (O'Connell et al., 2010; Murugaiyan et al., 2011). Interestingly, miR-155-3p ex- 
A
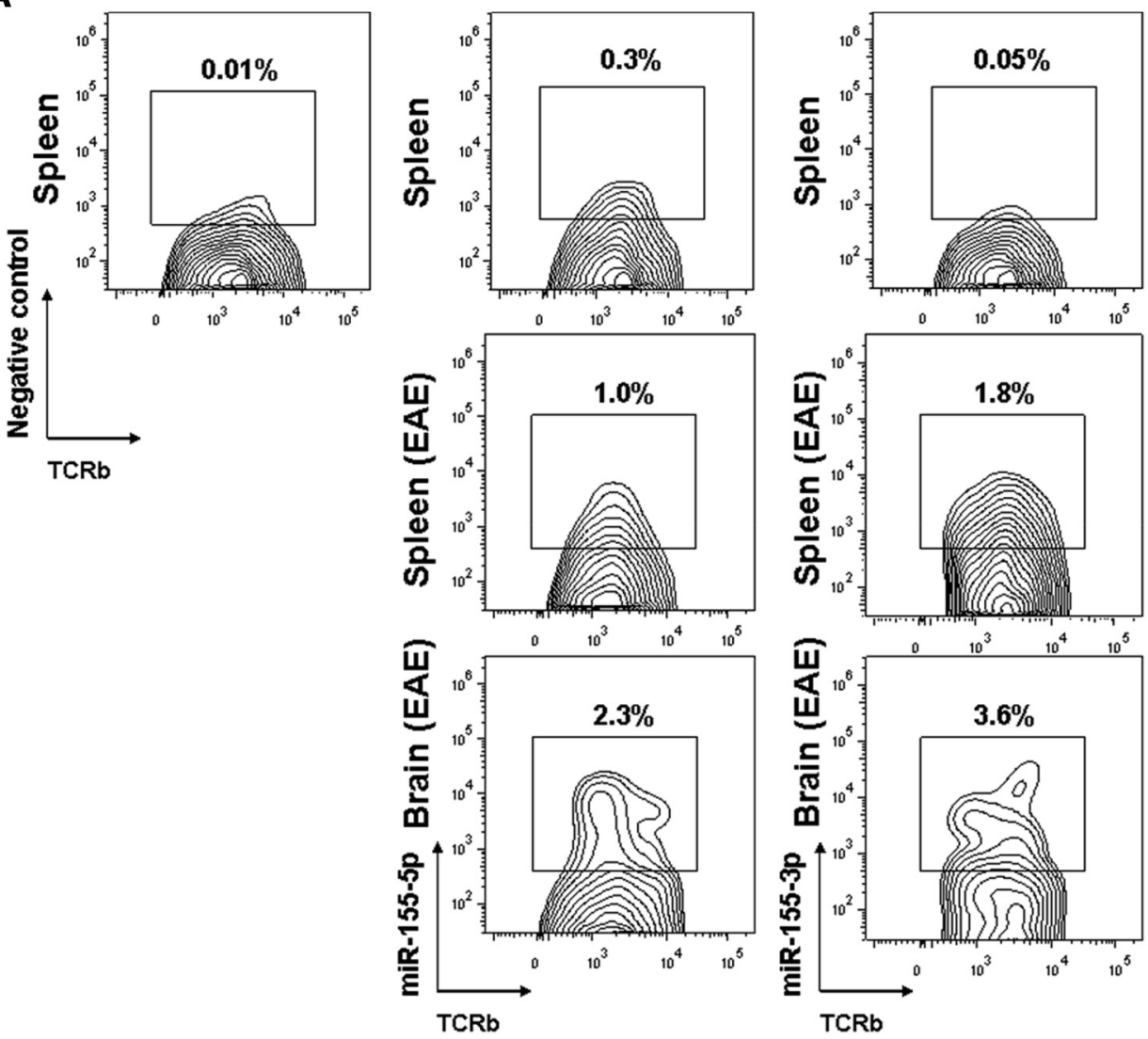

B

C

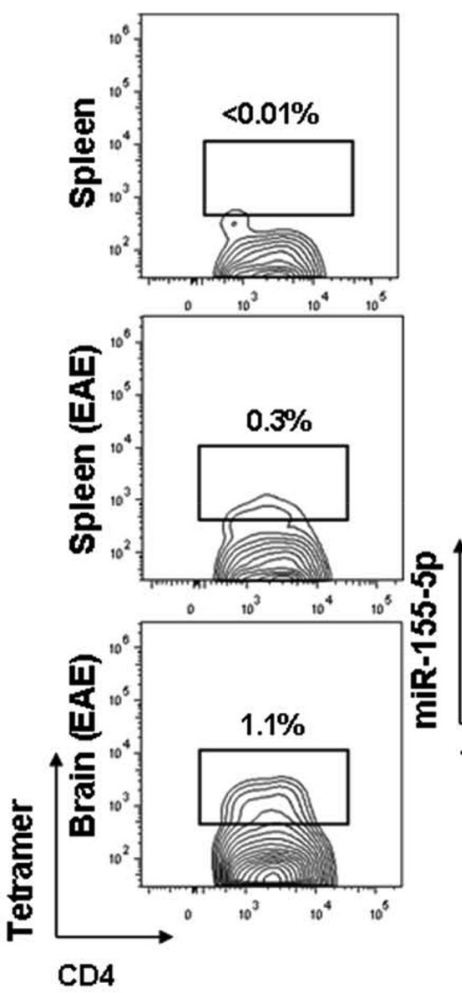

Tetramer positive Tetramer negative

Tetramer positive Tetramer negative
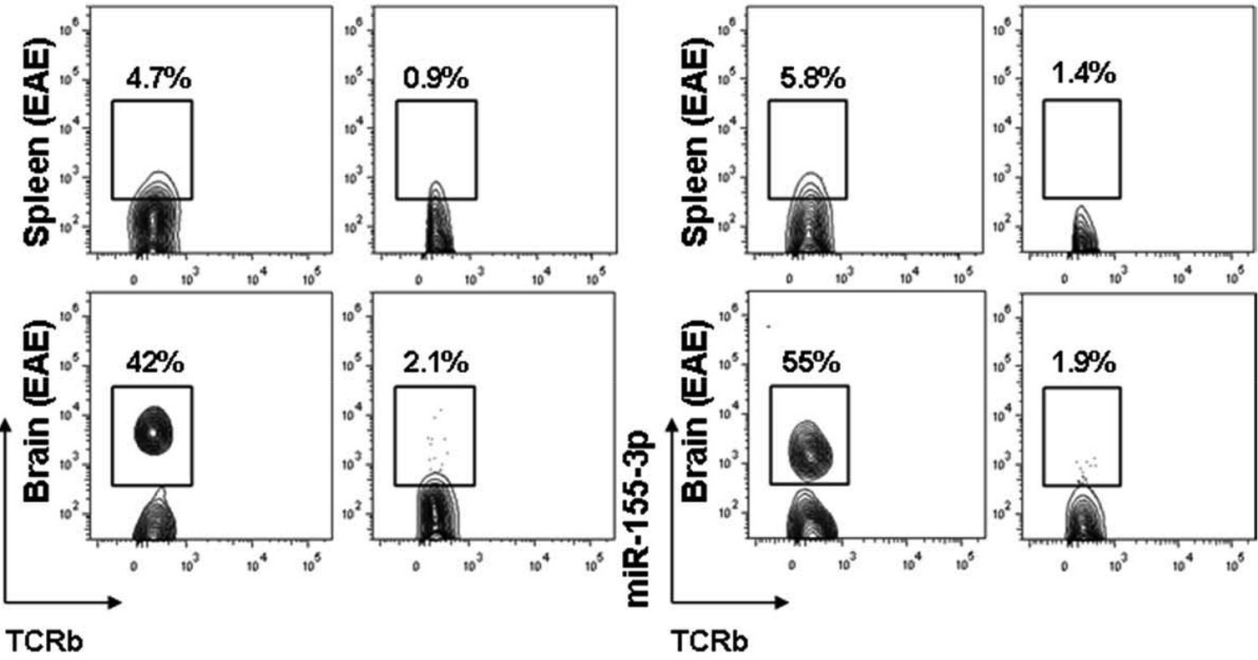

Figure 2. CNS-infiltrating myelin-reactive CD4 ${ }^{+} \mathrm{T}$ cells are highly enriched in miR-155-5p and miR-155-3p expression. $A$, Flow cytometry analysis of the gated CD4 ${ }^{+} \mathrm{T}$ cells from spleens of normal mice and from spleens and brains of mice with acute EAE (day 13) using miR-155-5p and miR-155-3p probes. Left, Example of staining of gated CD4 ${ }^{+} \mathrm{T}$ cells from spleens of normal mice with a negative control probe. Representative results from three independent experiments are shown. $\boldsymbol{B}$, Flow cytometry analysis of the gated CD4 ${ }^{+} \mathrm{T}$ cells from spleen of normal mice and from spleen and brain of mice with acute EAE (day 13) using an $\mathrm{IA}^{\mathrm{b}}-\mathrm{MOG}_{35-55}$ tetramer. Representative results from three independent experiments are shown. (Figure legend continues.) 
Gata3

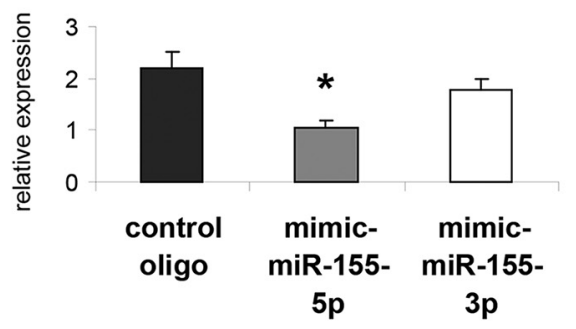

Tbx21

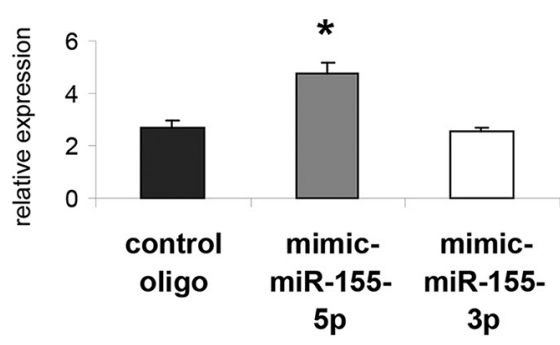

Rora

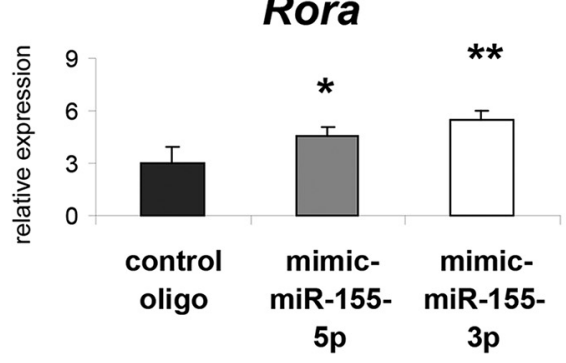

Foxp3

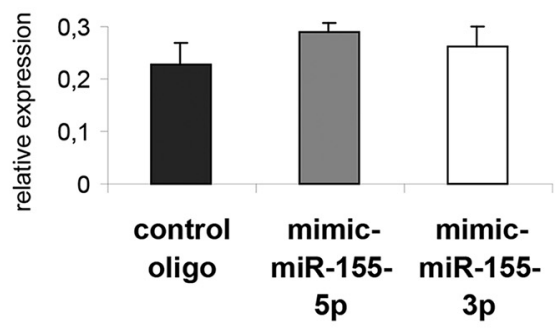

Ifng

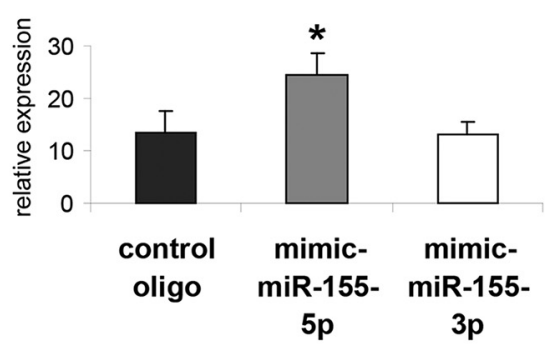

II17a

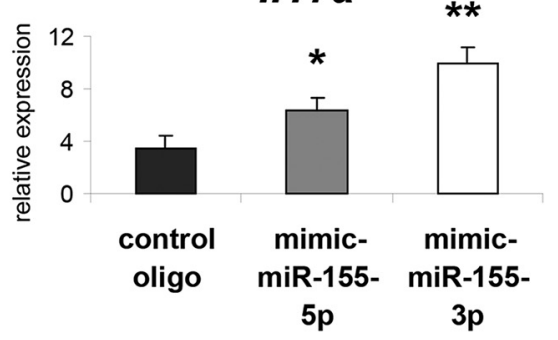

Figure 3. miR-155-5p and miR-155-3p upregulation affects CD4 ${ }^{+}$T-cell differentiation. Sorted splenic CD4 ${ }^{+} \mathrm{T}$ cells were transfected with mimic for miR-155-5p or mimic for miR-155-3p or with control oligonucleotide and subsequently stimulated with plate-bound anti-CD3 and anti-CD28 for $3 \mathrm{~d}$ and levels of expression of Gata3, Tbx21, Rora, Foxp3, Ifng, and II17a were measured. Data were normalized to expression levels in untreated Th cell cultures. Representative results (mean \pm SEM) from four independent experiments are shown. Data were analyzed by Student's $t$ test. ${ }^{*} p<0.01,{ }^{* *} p<0.001$.

pression in $\mathrm{CD}^{+}{ }^{+} \mathrm{T}$ cells resulted in even higher and more significant upregulation of the Th17 marker genes Rora and Ill7a compared with miR-155-5p-transfected cells, whereas miRNA155-3p did not significantly influence the Th1, Th2, or Treg Foxp3 marker gene expression (Fig. 3). Therefore, we have demonstrated that miR-155-3p upregulation in CD $4^{+}$T cells specifically promotes Th17 cell differentiation after TCR activation.

miR-155-3p in CD4 ${ }^{+}$T cells targets Dnaja2 and Dnajb1 To identify mRNA targets of miR-155 during development of the response to myelin autoantigen in vivo, we immunized miR-155sufficient and miR-155-deficient mice with $\mathrm{MOG}_{35-55}$. Twelve days later, PLN cells of immunized mice were stimulated in vitro with $\mathrm{MOG}_{35-55}$. Subsequently, $\mathrm{CD} 4{ }^{+} \mathrm{T}$ cells were purified and used as a source of RNA for a small-density qRT-PCR microarray analysis of mRNA expression. The results of mRNA expression profiling highlighted upregulation of two distinct transcripts, Dnaja2 and Dnajb1, in miR-155-deficient $\mathrm{CD}^{+}{ }^{+} \mathrm{T}$ cells after

(Figure legend continued.) C, Flow cytometry analysis of the gated IA ${ }^{\mathrm{b}}-\mathrm{MOG}_{35-55}$ tetramerpositive and -negative $\mathrm{CD} 4{ }^{+} \mathrm{T}$ cells, as depicted in $\boldsymbol{B}$, from spleens of normal mice and from spleens and brains of mice with acute EAE (day 13) using a miR-155-5p and miR-155-3p probes. Representative results from three independent experiments are shown.
$\mathrm{MOG}_{35-55}$ stimulation compared with miR-155-sufficient cells (Fig. 4A). Therefore, we have identified two hsp40 family genes transcripts, Dnaja2 and Dnajb1, as putative targets of miR-155 in $\mathrm{CD}^{+}{ }^{+} \mathrm{T}$ cells.

To identify which of the two miR-155 strands, miR-155-5p or miR-155-3p, was responsible for the silencing of the Dnaja2 and Dnajb1 transcripts, we transfected an antagomir for miR-155-5p, an antagomir for miR-155-3p, or a control oligonucleotide into splenic CD4 ${ }^{+} \mathrm{T}$ cells from the miR-155-sufficient mice from day 12 after immunization with $\mathrm{MOG}_{35-55}$. Subsequently, these cells were stimulated in vitro with $\mathrm{MOG}_{35-55}$ and $\mathrm{CD}^{+}{ }^{+} \mathrm{T}$ cells were purified and used as a source of RNA for Dnaja2 and Dnajb1 expression analysis. We found that miR-155-5p antagomir transfection did not result in a significant upregulation of either hsp40 transcript, whereas miR-155-3p antagomir led to a significant upregulation of both Dnaja2 and Dnajb1 (Fig. 4B). Therefore, we have revealed that miR-155-3p presence in $\mathrm{CD}^{+}{ }^{+} \mathrm{T}$ cells, but not miR-155-5p, is responsible for changes in expression of Dnaja2 and Dnajb.

Next, using a luciferase reporter system, we sought to confirm these findings and to test whether miR-155-3p interacts directly with Dnaja2 or Dnajb1 3'-UTR. HEK-293 cells were transfected with either a construct containing the full-length Dnaja2 3'-UTR sequence downstream of firefly luciferase or a construct containing the full-length Dnajb1 3'-UTR sequence downstream of firefly luciferase. Cells transfected with either of the vectors showed luciferase activity that was inhibited by cotransfection with a mimic for miR$155-3$ p by at least $50 \%$ for both Dnaja2 $3^{\prime}$-UTR and Dnajb1 $3^{\prime}$-UTR constructs (Fig. 4C). In contrast, neither transfection of miR-155-5p mimic nor a control oligonucleotide into cells expressing both 3' UTR transcripts affected luciferase activity. These data confirm that miR-155-3p, but not miR-155-5p, targets both Dnaja2 and Dnajb1 mRNA directly and reduces their expression.

\section{Dnaja2 and Dnajb1 overexpression inhibits Th17 development}

To understand the mechanism of miR-155-3p control of Th17 differentiation, we needed to examine the function of Dnaja2 and Dnajb1 gene expression in CD $4^{+} \mathrm{T}$ cells. Therefore, we transfected $\mathrm{CD}^{+}{ }^{+} \mathrm{T}$ cells from naive mice spleens with plasmids expressing either the Dnaja2 or the Dnajb1 gene. To ensure maximum transfection efficiency, cells were sorted after transfection based on the presence of GFP expression (co-encoded in the plasmids). Subsequently, cells were stimulated with anti-CD3 and used for both protein and RNA expression analysis. The effectiveness of both individual Dnaja2 and Dnajb1 overexpression and cooverexpression in CD4 ${ }^{+} \mathrm{T}$ cells is shown in Figure $5 \mathrm{~A}$. Overexpression of either Dnaja2 or Dnajb1 resulted in significant 
A

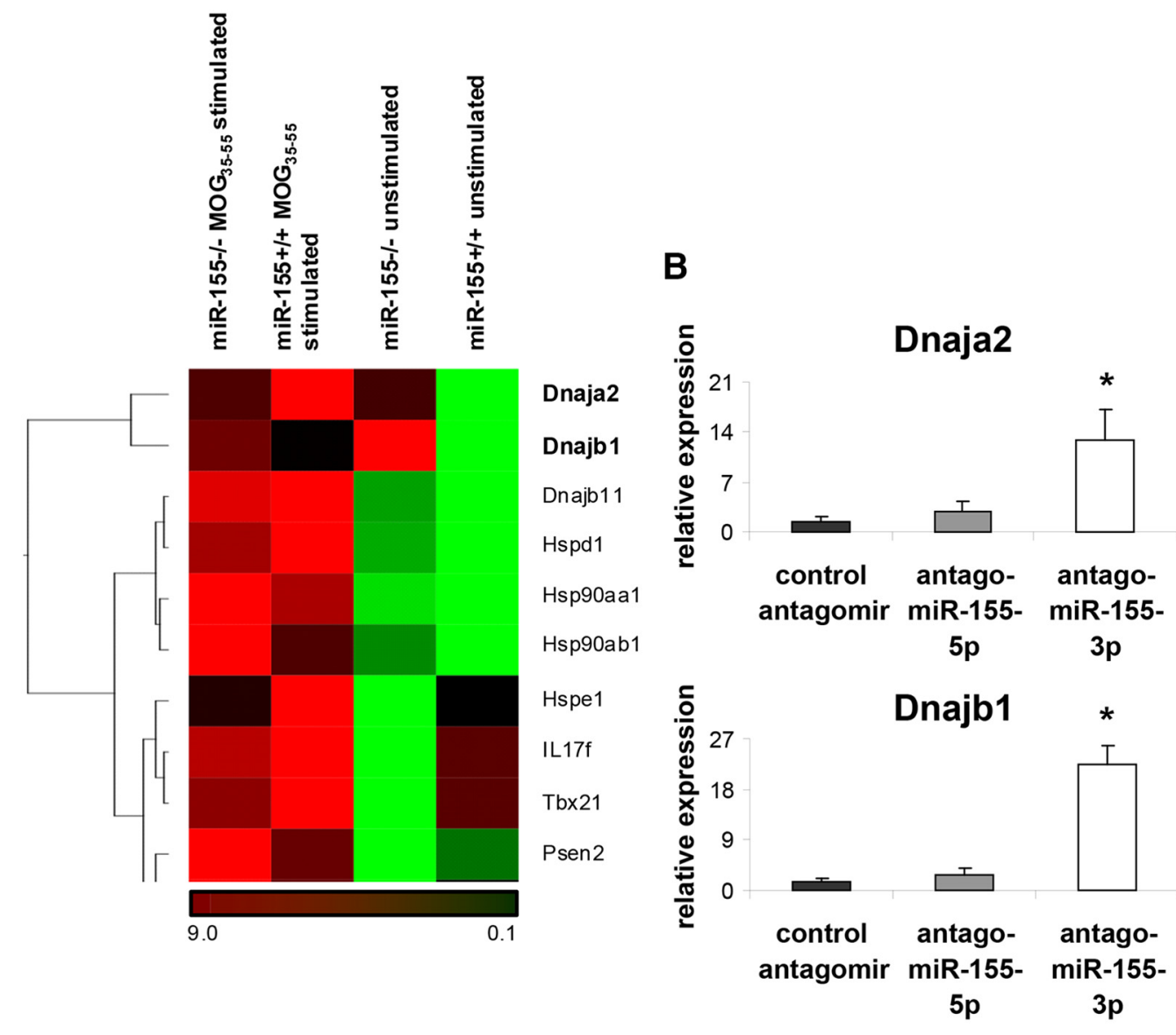

C

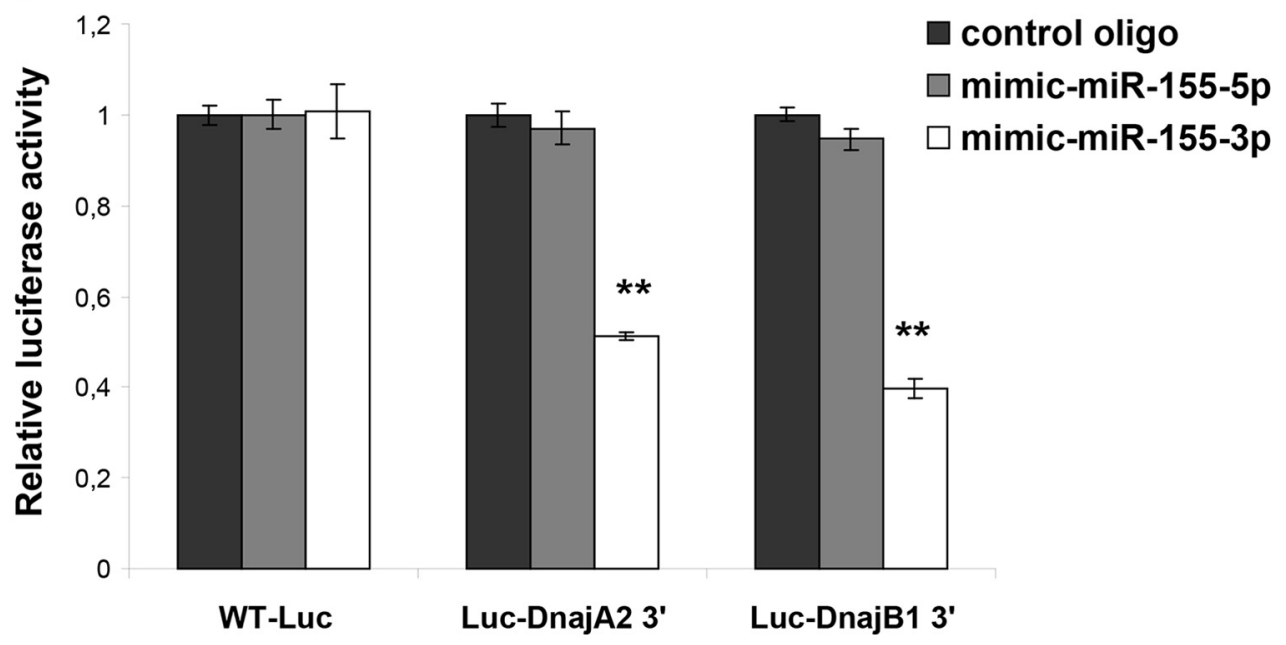

Figure 4. Hsp40 genes transcripts are direct targets of miR-155-3p in CD4 ${ }^{+} \mathrm{T}$ cells. A, miR-155-deficient and miR-155-sufficient CD4 ${ }^{+} \mathrm{T}$ cells from M0G ${ }_{35-55}$-immunized mice were in vitro stimulated with either $\mathrm{MOG}_{35-55}(20 \mu \mathrm{g} / \mathrm{ml})$ or left unstimulated and mRNA expression changes were analyzed by small-density arrays. Heat map displays genes reportedly upregulated in miR-155 deficient $C D 4^{+}$T cells after $\mathrm{MOG}_{35-55}$ stimulation. Gene expressions are grouped using hierarchical clustering. $\boldsymbol{B}$, Spleen cells of mice immunized $12 \mathrm{~d}$ earlier with $M O G_{35-55}$ were transfected with antagomirs against miR-155-3p, miR-155-5p, or control antagomir or untransfected after in vitro restimulation for $3 \mathrm{~d}$ with $\mathrm{MOG}_{35-55}(20 \mu \mathrm{g} / \mathrm{ml})$. Subsequently, $\mathrm{CD}^{+}{ }^{+} \mathrm{T}$ cells were sorted and the RNA analyzed for expression levels of Dnaja2 and Dnajb1 with qRT-PCR. Data were normalized to the expression levels in CD4 ${ }^{+} \mathrm{T}$ cells from untransfected cultures. Representative results (mean \pm SEM) from three independent experiments are shown. Data were analyzed by Student's $t$ test. ${ }^{*} p<0.01$. C, Luciferase activity in HEK-293 cells transfected with reporter constructs containing either wild-type firefly luciferase or luciferase with Dnaja2 $3^{\prime}$-UTR or luciferase with Dnajb13' -UTR. The HEK-293 cell line was cotransfected with the indicated constructs and either mimic for miR-155-3p or mimic for miR-155-5p or control oligonucleotide. Normalized levels of luciferase activity are shown. Representative results (mean \pm SEM) from two independent experiments are shown. Data were analyzed by Student's $t$ test. ${ }^{* *} p<0.001$. 
A

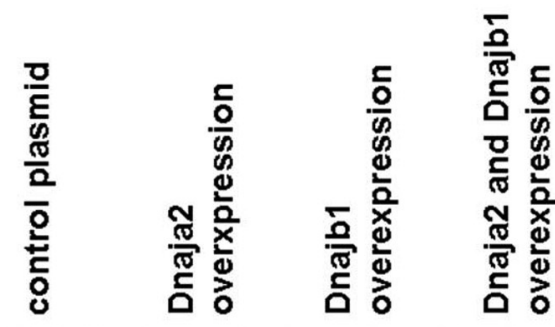

DNAJA2

DNAJB1

B

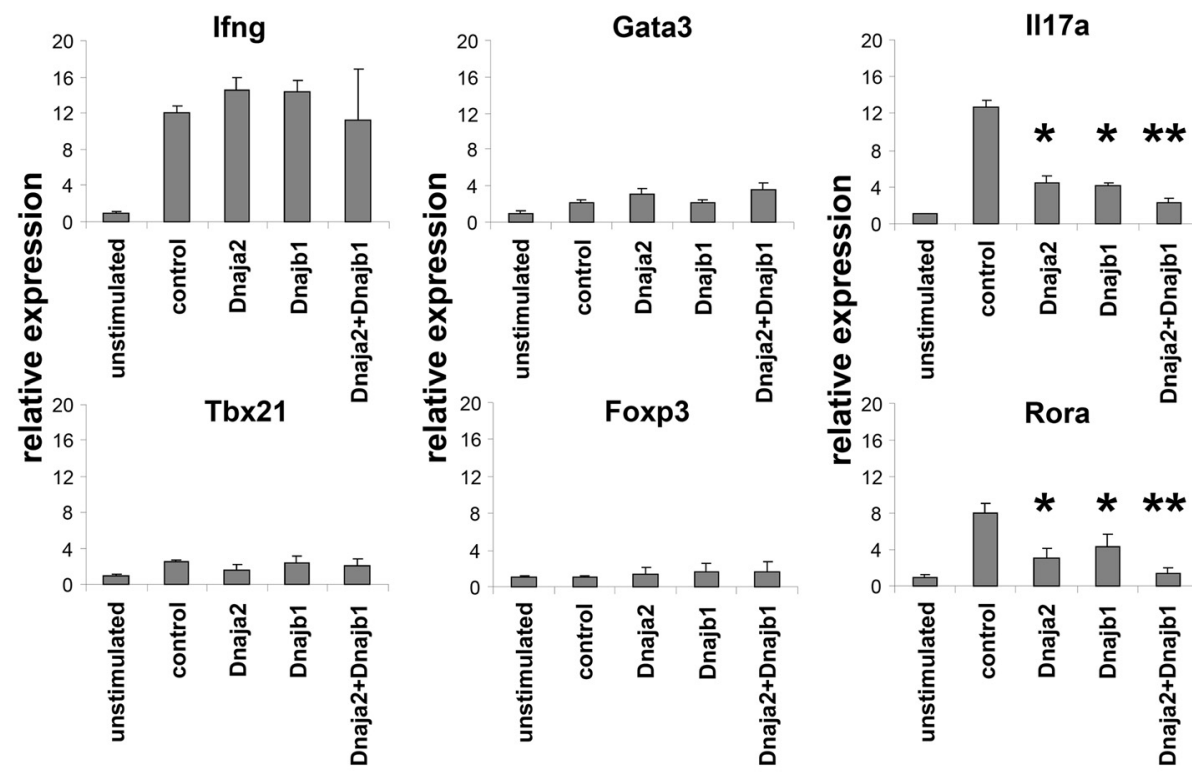

C

Control vector

Dnaja2

Dnajb1

Dnaja2 and Dnajb1 overexpression overexpression overexpression
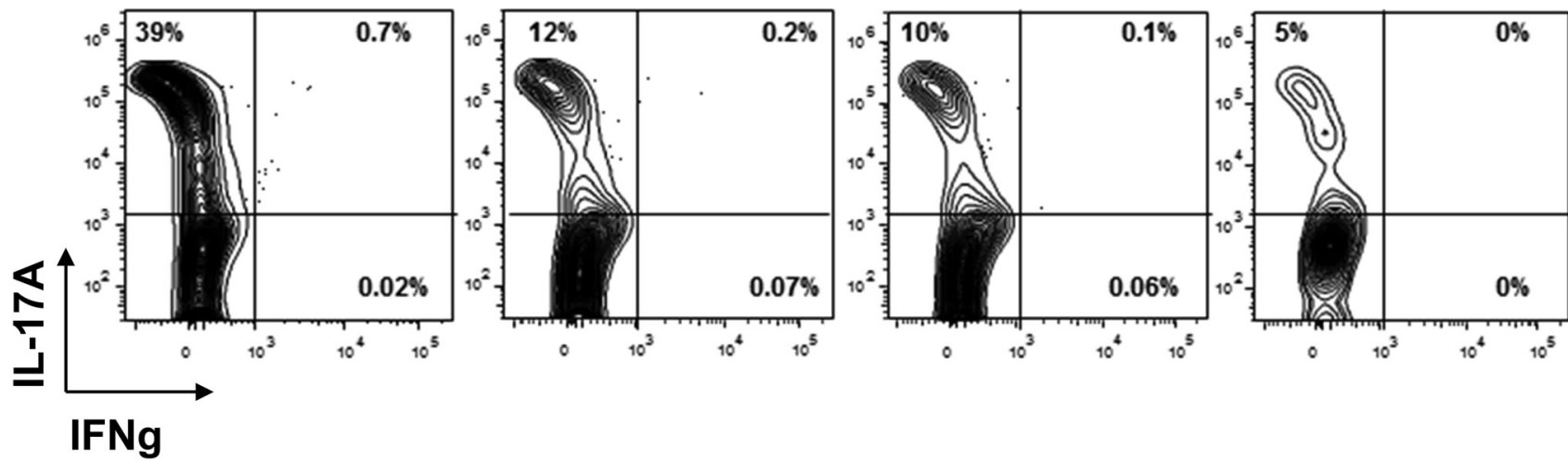

Figure 5. Dnaja2 and Dnajb1 expression inhibits Th17 development. $A$, Western blot analysis of DNAJA2, DNAJB1, and GAPDH proteins in CD4 ${ }^{+}$T cells that were transfected with respective genes overexpression plasmids. Representative results from two independent experiments are shown. $\boldsymbol{B}$, Sorted splenic CD4 ${ }^{+} \mathrm{T}$ cells were transfected with either (Figure legend continues.) 
A

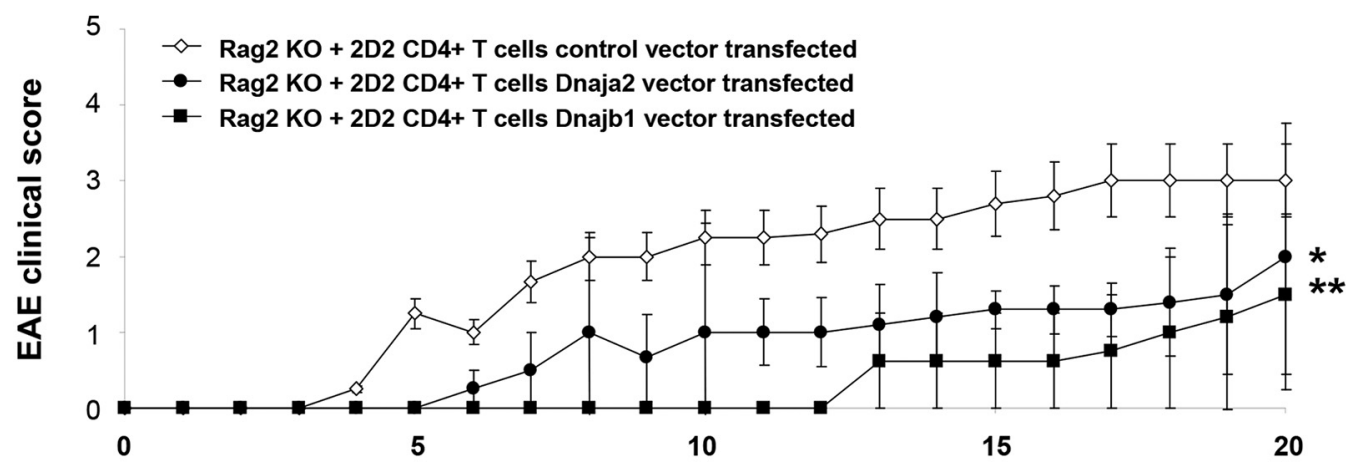

Days post disease induction

B

\begin{tabular}{c|c|c|c|c}
\hline Mice & $\begin{array}{c}\text { EAE } \\
\text { incidence }\end{array}$ & $\begin{array}{c}\text { Cumulative } \\
\text { EAE score }\end{array}$ & $\begin{array}{c}\text { Maximum } \\
\text { EAE score }\end{array}$ & $\begin{array}{c}\text { Day of EAE } \\
\text { onset }\end{array}$ \\
\hline $\begin{array}{c}\text { Rag2 KO + 2D2 CD4+ T } \\
\text { cells control vector } \\
\text { transfected }\end{array}$ & $5 / 5$ & $37 \pm 11$ & $3 \pm 0.5$ & $5 \pm 0.5$ \\
\hline $\begin{array}{c}\text { Rag2 KO + 2D2 CD4+ T } \\
\text { cells Dnaja2 vector } \\
\text { transfected }\end{array}$ & $5 / 5$ & $16 \pm 9 *$ & $2 \pm 0.3^{*}$ & $6 \pm 0.5$ \\
\hline $\begin{array}{c}\text { Rag2 KO + 2D2 CD4+ T } \\
\text { cells Dnajb1 vector } \\
\text { transfected }\end{array}$ & $4 / 5$ & $7 \pm 3^{*}$ & $1.5 \pm 0.3 *$ & $13 \pm 1^{*}$ \\
\hline
\end{tabular}

Figure 6. Dnaja2 and Dnajb1 overexpression in $\mathrm{CD}_{4}^{+} \mathrm{T}$ cells results ameliorates EAE. A, $\mathrm{MOG}_{35-55^{-}}-\mathrm{TCR}$ transgenic CD4 ${ }^{+} \mathrm{T}$ cells (2D2) were isolated and in vitro transfected with either Dnaja2 or Dnajb1 overexpression plasmid or with control vector and transferred to Rag2 $\mathrm{KO}$ that were subsequently induced for EAE with $\mathrm{MOG}_{35-55}$. Clinical scores of the mice are presented (mean \pm SEM). Five mice per group were used. Asterisks indicate significant differences (Mann-Whitney $U$ test; ${ }^{*} p<0.03,{ }^{* *} p<0.02$ ). B, Summary of EAE clinical data show that Rag2 K0 mice that has been transferred with either Dnaja2 or Dnajb1 overexpression plasmid transfected 2D2 T cells displayed a very benign disease (Student's $t$ test; ${ }^{*} p<0.001$ ).

downregulation of expression of the Th17 marker genes Rora and Il17a (Fig. 5B). Even greater downregulation of expression resulted from overexpression of both Dnaja2 and Dnajb1 in CD ${ }^{+}$ $\mathrm{T}$ cells, suggesting a synergistic effect of both hsp40 genes. In contrast, the expression of gene markers for Th1 (Tbx21 and Ifng), Th2 (Gata3), and Treg (Foxp3) did not show significant differences after overexpression of Dnaja2, Dnajb1, or both genes (Fig. 5B). This gene expression profile mirrors the changes seen after miR-155-3p mimic transfection into CD ${ }^{+} \mathrm{T}$ cells (Fig. 3), which further confirms the opposing functional effects of miR155-3p and Dnaja2 and Dnajb1 genes on Th17 cell development.

To confirm further the effect of Dnaja2 and Dnajb1 gene expression on Th17 differentiation, we overexpressed both genes in naive $\mathrm{CD} 4{ }^{+} \mathrm{T}$ cells and cultured them in vitro under Th17 polarizing conditions. Dnaja2 or Dnajb1 overexpression resulted in profound inhibition of Th17 in vitro differentiation, which,

(Figure legend continued.) Dnaja2 or Dnajb1 or both genes' overexpression plasmid or with control vector and subsequently stimulated with plate-bound anti-CD3 and anti-CD28 for $3 \mathrm{~d}$ and levels of expression of Gata3, Tbx21, Rora, Foxp3, Ifng, and II17a were measured. Data were normalized to expression levels in untreated Th cell cultures. Representative results (mean \pm SEM) from three independent experiments are shown. Data were analyzed by Student's $t$ test. ${ }^{*} p<0.04,{ }^{* *} p<0.01$. C, Naive CD4 ${ }^{+}$T cells were transfected with either Dnaja2 or Dnajb1 or both genes' overexpression plasmid or with control vector and were stimulated in vitro with plate bound anti-CD3 and anti-CD2, in the Th17 condition (in the presence of IL-6, TGFb, IL-1b, IL-23, anti-IFNg, and anti-IL-4) and assayed for the secretion of IL-17 and IFNg by intracellular flow cytometry on day 6 after the start of stimulation. The data show gated transfected (GFPpositive) cells. Representative results from three independent experiments are shown. again, was further augmented by cooverexpression of both genes (Fig. 5C). Therefore, we have demonstrated that either Dnaja2 or Dnajb1 gene overexpression or, particularly, cooverexpression of both genes, profoundly hinders Th17 differentiation.

\section{Dnaja2 and Dnajb1 overexpression in myelin-reactive CD4 ${ }^{+}$}

$T$ cells diminishes their encephalitogenic potential

These data suggest that Dnaja2 and Dnajb1 transcripts are important intermediates of miR-155-3p function in CD $4^{+} \mathrm{T}$ cells in relation to Th17 differentiation. Accordingly, we tested the effect of overexpression of Dnaja2 and Dnajb1 genes on EAE development. We overexpressed Dnaja2 or Dnajb1 in $\mathrm{MOG}_{35-55}$-TCR $\mathrm{CD}^{+}{ }^{+} \mathrm{T}$ cells (2D2) and transferred them into Rag2-deficient mice. The results showed that all animals that received $2 \mathrm{D} 2$ cells transfected with a control plasmid developed severe EAE over the $20 \mathrm{~d}$ observation period (Fig. $6 A, B$ ). In contrast, the group that received $2 \mathrm{D} 2 \mathrm{CD}^{+}{ }^{+} \mathrm{T}$ cells with either overexpression of Dnaja2 or overexpression of Dnajb1 developed a very mild EAE (Fig. $6 A, B)$. These data demonstrate that in vivo expression of either the Dnaja2 or Dnajb1 gene contributes to regulation of myelinreactive $\mathrm{CD} 4^{+} \mathrm{T}$ cells and the development of autoimmune demyelination.

\section{Discussion}

Our findings indicate that development of myelin antigenspecific $\mathrm{CD}^{+}{ }^{+}$T-cell responses correlates with significant changes in expression of miR-155 in both peripheral and braininfiltrating T cells. Specifically, we found that a previously iden- 
tified passenger strand, miR-155-3p, is highly upregulated and represents a significant form of miRNA-155 in T helper cells during EAE. Mechanistic studies showed that miR-155-3p influenced the development of Th17 cells. A molecular search highlighted and validated two Hsp40 genes, Dnaja2 and Dnajb1, as direct targets of miR-155-3p in CD4 ${ }^{+} \mathrm{T}$ cells. In vitro studies with Dnaja2 and Dnajb1 overexpression in $\mathrm{CD}^{+}{ }^{+} \mathrm{T}$ cells demonstrated their inhibitory role in Th17 development. In vivo studies in animals with EAE demonstrated a specific role for transcripts of these two genes in $\mathrm{CD} 4{ }^{+} \mathrm{T}$ cells in the suppression of EAE. Therefore, we have demonstrated for the first time a significant and specific role for a passenger strand of miR-155-3p in the regulation of autoimmune demyelination and have identified its target molecules, Dnaja2 and Dnajb1 gene transcripts, as critical players in this process.

Many observations have demonstrated an association between miR-155 expression and T-cell differentiation. miR-155 was among the first miRNAs identified to operate in $\mathrm{CD} 4{ }^{+} \mathrm{T}$ cells, and its expression has been linked with T-cell activation after TCR stimulation (Haasch et al., 2002; Jindra et al., 2010; Loeb et al., 2012). A role for miR-155 in CD4 ${ }^{+}$T-cell biology has recently been studied intensively. miR-155 has been shown to maintain competitive fitness of $\mathrm{T}$ regulatory cell subsets by targeting suppressor of cytokine signaling 1 (SOCS1) expression ( $\mathrm{Lu}$ et al., 2009). A decreased capacity of miR-155-deficient CD4 ${ }^{+} \mathrm{T}$ cells to develop into the $\mathrm{T}$ follicular helper cell lineage has been linked to lack of inhibition of transcripts that regulate the NF-kB (Ikbke and Peli1) and AP-1 (Fosl2) pathways (Hu et al., 2014). The absence of miR-155 has also been reported to influence Th1 development (O'Connell et al., 2010; Oertli et al., 2011; Escobar et al., 2013). Furthermore, in mice deficient in miR-155, increased numbers of Th2 cells has been linked to miR-155 targeting of the transcript of the Th2-promoting transcriptional factor c-Maf (Rodriguez et al., 2007). Finally, a number of reports have confirmed a crucial and intrinsic role for miR-155 in Th17 development, in which transcripts such as Jarid2 (Escobar et al., 2014) and Ets1 (Hu et al., 2013) have been suggested to mediate the miR-155 effect on Th17 development. However, none of these studies differentiated between the effects of the two strands of miRNA-155.

T-cell differentiation disturbance can lead to autoimmunity and mice with no expression of miR-155 were shown to develop an increased inflammatory remodeling of lung airways as a result of Th2 overproduction (Rodriguez et al., 2007). miR-155deficient mice have been reported to be resistant to EAE and many cellular populations, both in the CNS and the periphery, are likely to contribute to this effect (O'Connell et al., 2010; Murugaiyan et al., 2011). We have reported previously that, during EAE, many CNS-infiltrating immune cells, including T cells, have significantly upregulated miR-155 expression (Mycko et al., 2012). We have confirmed these observations with the recent data but, more importantly, we have found that, in sorted CD4 ${ }^{+}$ T cells from CNS of EAE animals, both strands of miRNA-155 are present and express a high copy number per cell. Unexpectedly, a detailed analysis showed that miR-155-3p was induced at an even higher level than the "leading" strand, miRNA-155-5p. The significance of this finding was supported by the observation that miR-155-3p was not detected in the non-T-cell CD11b ${ }^{+}$population of cells in the CNS of the EAE animals and has also not been found in healthy mice. Therefore, we have identified miR-155-3p as a specific form of miR-155 in CD4 ${ }^{+} \mathrm{T}$ cells in EAE.

Every miRNA-encoding gene contains information for two strands of the mature miRNA and these two strands form a du- plex (Wang et al., 2009). Classically, it has been assumed that, upon loading of miRNA duplexes into AGO protein, only one of these strands, called a "leading" strand, stays bound to AGO, whereas the other strand, called a "passenger," is destroyed and does not contribute to RISC activity. The mechanisms controlling this strand selection process are not well understood and depend upon cell type, development stage, and activation status (Meijer et al., 2014). Therefore, it seems that strand selection is a tightly controlled process. Indeed, a number of reports for various miRNAs have demonstrated that both strands can be coaccumulated in some tissues and functionally suppress their specific targets, challenging the concept of a dispensable role for a miRNA passenger strand (Ro et al., 2007; Chiang et al., 2010; Carrer et al., 2012). Interestingly, the presence of both products of the miR-155 has already been demonstrated for some cell types, such as plasmocytoid dendritic cells (Zhou et al., 2010) and astrocytes (Tarassishin et al., 2011), suggesting their cooperative involvement in cell function. Our findings demonstrate the presence of miR-155-3p in CD4 ${ }^{+} \mathrm{T}$ cells during EAE, but not in healthy mice. The effect of miRNA-155 strand selection leading to modification of $\mathrm{CD} 4{ }^{+} \mathrm{T}$-cell function during EAE appears to be highly selective because we have not seen passenger strands of miR-21 or miR-301a to be present in the same cell population during the same conditions (M.P.M., M.C., K.W.S., unpublished data). Therefore, our data suggest highly adaptive mechanisms of miR-155 biogenesis in CD4 ${ }^{+} \mathrm{T}$ cells. It has been demonstrated that transcriptional and posttranscriptional mechanisms cooperate to rapidly reprogram the miRNA repertoire in differentiating $\mathrm{T}$ cells, including modulation of RISC complex protein expression (Bronevetsky et al., 2013). Recently, we have reported a dysregulation of the RISC assembly in the CNS during EAE (Lewkowicz et al., 2015). For example, AGO2 and FXR1 were significantly downregulated in the infiltrating $\mathrm{T}$ cells from EAE brain. It is likely that these RISC changes contribute to the modification of the miRNA strand selection process and emergence of miR-155-3p in CD4 ${ }^{+} \mathrm{T}$ cells during EAE.

The presence of both strands of the miR-155 significantly expands the spectrum of potential RNA targets because the seeding sequences of miR-155-5p and miR-155-3p are different. In an attempt to identify the targets of the miR-155-3p in CD ${ }^{+} \mathrm{T}$ cells during EAE, we compared the mRNA profiles of $\mathrm{CD} 4{ }^{+} \mathrm{T}$ cells from EAE of both miR-155-sufficient and miR-155-deficient animals. Transcripts of two hsp40 genes, Dnaja2 and Dnajb1, have been found to be most significantly upregulated in the miR-155deficient $\mathrm{CD}^{+}{ }^{+} \mathrm{T}$ cells after in vitro restimulation with myelin antigen. Subsequent in vitro analyses revealed that Dnaja 2 and Dnajb1 are targeted by miR-155-3p, but not by miR-155-5p. The presence of these two hsp 40 gene transcripts in the AGO complex in $\mathrm{CD} 4{ }^{+} \mathrm{T}$ cells has already been revealed by differential HITSCLIP analysis (Loeb et al., 2012). We now demonstrate that they represent direct targets of miR-155-3p. Not much is known about the role of hsp 40 in CD $4{ }^{+} \mathrm{T}$ cells. HSP40 family members are HSP70 co-chaperones that determine the fate of HSP70 clients by facilitating protein folding, assembly, and degradation (Kampinga and Craig, 2010). HSP40 proteins, including DNAJA2 and DNAJB1, select substrates for HSP70 and help at precise locations of HSP70 in cells (Rauch and Gestwicki, 2014). We and others have demonstrated a critical role of HSP70 in the development of autoimmune responses toward myelin antigen for CD4 ${ }^{+}$T cells (Mycko et al., 2008; Mansilla et al., 2014), antigen-presenting cells (Cwiklinska et al., 2003; Mycko et al., 2004), and NK cells (Galazka et al., 2014). We now demonstrate that DNAJA2 and DNAJB1, HSP70 chaperones, are CD4 ${ }^{+}$ 
T-cell-intrinsic factors involved in the inhibition of Th17 development and limit their encephalitogenic potential. Therefore, we have identified a novel axis operating in the $\mathrm{CD} 4{ }^{+} \mathrm{T}$ cells during autoimmune demyelination that is dependent on the upregulation of miR-155-3p and subsequent suppression of Dnaja2 and Dnajb1.

In summary, our findings demonstrate for the first time the role of miR-155-3p and its targets, Dnaja2 and Dnajb1, in the development of Th17 cells and in the regulation of EAE. Accumulating data suggest strongly that Th17 cells represent a divergent population consisting of both pathogenic and nonpathogenic cells (Ghoreschi et al., 2010; Ghoreschi et al., 2011; Lee et al., 2012). We have found that myelin-antigen-specific $\mathrm{CD}^{+} \mathrm{T}$ cells infiltrating the CNS during EAE, a population known to represent mostly IL-17-producing cells (Duhen et al., 2013), are highly enriched in miR-155-3p. Collectively, our results suggest that miR-155-3p is an encephalitogenic, Th17subset-associated miRNA that functions in the pathogenesis of autoimmune demyelination. Because the expression of this miRNA appears to be selective during EAE, miR-155-3p might represent an important target for potential therapeutic intervention that would selectively tackle autoreactive $\mathrm{CD} 4{ }^{+} \mathrm{T}$ cells.

\section{References}

Bettelli E, Carrier Y, Gao W, Korn T, Strom TB, Oukka M, Weiner HL, Kuchroo VK (2006) Reciprocal developmental pathways for the generation of pathogenic effector TH17 and regulatory T cells. Nature 441:235238. CrossRef Medline

Bettelli E, Korn T, Oukka M, Kuchroo VK (2008) Induction and effector functions of T(H) 17 cells. Nature 453:1051-1057. CrossRef Medline

Bronevetsky Y, Villarino AV, Eisley CJ, Barbeau R, Barczak AJ, Heinz GA, Kremmer E, Heissmeyer V, McManus MT, Erle DJ, Rao A, Ansel KM (2013) T cell activation induces proteasomal degradation of Argonaute and rapid remodeling of the microRNA repertoire. J Exp Med 210:417432. CrossRef Medline

Carrer M, Liu N, Grueter CE, Williams AH, Frisard MI, Hulver MW, BasselDuby R, Olson EN (2012) Control of mitochondrial metabolism and systemic energy homeostasis by microRNAs 378 and $378^{*}$. Proc Natl Acad Sci U S A 109:15330-15335. CrossRef Medline

Chiang HR, Schoenfeld LW, Ruby JG, Auyeung VC, Spies N, Baek D, Johnston WK, Russ C, Luo S, Babiarz JE, Blelloch R, Schroth GP, Nusbaum C, Bartel DP (2010) Mammalian microRNAs: experimental evaluation of novel and previously annotated genes. Genes Dev 24:992-1009. CrossRef Medline

Cua DJ, Sherlock J, Chen Y, Murphy CA, Joyce B, Seymour B, Lucian L, To W, Kwan S, Churakova T, Zurawski S, Wiekowski M, Lira SA, Gorman D, Kastelein RA, Sedgwick JD (2003) Interleukin-23 rather than interleukin-12 is the critical cytokine for autoimmune inflammation of the brain. Nature 421:744-748. CrossRef Medline

Cwiklinska H, Mycko MP, Luvsannorov O, Walkowiak B, Brosnan CF, Raine CS, Selmaj KW (2003) Heat shock protein 70 associations with myelin basic protein and proteolipid protein in multiple sclerosis brains. Int Immunol 15:241-249. CrossRef Medline

Duhen R, Glatigny S, Arbelaez CA, Blair TC, Oukka M, Bettelli E (2013) Cutting edge: the pathogenicity of IFN-gamma-producing Th17 cells is independent of T-bet. J Immunol 190:4478-4482. CrossRef Medline

Escobar TM, Kanellopoulou C, Kugler DG, Kilaru G, Nguyen CK, Nagarajan V, Bhairavabhotla RK, Northrup D, Zahr R, Burr P, Liu X, Zhao K, Sher A, Jankovic D, Zhu J, Muljo SA (2014) miR-155 activates cytokine gene expression in Th17 cells by regulating the DNA-binding protein Jarid 2 to relieve polycomb-mediated repression. Immunity 40:865-879. CrossRef Medline

Escobar T, Yu CR, Muljo SA, Egwuagu CE (2013) STAT3 activates miR-155 in Th17 cells and acts in concert to promote experimental autoimmune uveitis. Invest Ophthalmol Vis Sci 54:4017-4025. CrossRef Medline

Eugster HP, Frei K, Kopf M, Lassmann H, Fontana A (1998) IL-6-deficient mice resist myelin oligodendrocyte glycoprotein-induced autoimmune encephalomyelitis. Eur J Immunol 28:2178-2187. CrossRef Medline

Galazka G, Jurewicz A, Domowicz M, Cannella B, Raine CS, Selmaj K (2014)
HINT1 peptide/Hsp70 complex induces NK-cell-dependent immunoregulation in a model of autoimmune demyelination. Eur J Immunol 44:3026-3044. CrossRef Medline

Ghoreschi K, Laurence A, Yang XP, Tato CM, McGeachy MJ, Konkel JE, Ramos HL, Wei L, Davidson TS, Bouladoux N, Grainger JR, Chen Q, Kanno Y, Watford WT, Sun HW, Eberl G, Shevach EM, Belkaid Y, Cua DJ, Chen W, et al. (2010) Generation of pathogenic T(H)17 cells in the absence of TGF-beta signalling. Nature 467:967-971. CrossRef Medline

Ghoreschi K, Laurence A, Yang XP, Hirahara K, O'Shea JJ (2011) T helper 17 cell heterogeneity and pathogenicity in autoimmune disease. Trends Immunol 32:395-401. CrossRef Medline

Haasch D, Chen YW, Reilly RM, Chiou XG, Koterski S, Smith ML, Kroeger P, McWeeny K, Halbert DN, Mollison KW, Djuric SW, Trevillyan JM (2002) T cell activation induces a noncoding RNA transcript sensitive to inhibition by immunosuppressant drugs and encoded by the protooncogene, BIC. Cell Immunol 217:78-86. CrossRef Medline

Hafler DA (2004) Multiple sclerosis. J Clin Invest 113:788-794. CrossRef Medline

Hu R, Huffaker TB, Kagele DA, Runtsch MC, Bake E, Chaudhuri AA, Round JL, O’Connell RM (2013) MicroRNA-155 confers encephalogenic potential to Th17 cells by promoting effector gene expression. J Immunol 190:5972-5980. CrossRef Medline

Hu R, Kagele DA, Huffaker TB, Runtsch MC, Alexander M, Liu J, Bake E, Su W, Williams MA, Rao DS, Möller T, Garden GA, Round JL, O'Connell RM (2014) miR-155 Promotes $\mathrm{T}$ follicular helper cell accumulation during chronic, low-grade inflammation. Immunity 41:605-619. CrossRef Medline

Jindra PT, Bagley J, Godwin JG, Iacomini J (2010) Costimulationdependent expression of microRNA-214 increases the ability of T cells to proliferate by targeting Pten. J Immunol 185:990-997. CrossRef Medline

Jinek M, Doudna JA (2009) A three-dimensional view of the molecular machinery of RNA interference. Nature 457:405-412. CrossRef Medline

Kampinga HH, Craig EA (2010) The HSP70 chaperone machinery: J proteins as drivers of functional specificity. Nat Rev Mol Cell Biol 11:579_ 592. CrossRef Medline

Lee Y, Awasthi A, Yosef N, Quintana FJ, Xiao S, Peters A, Wu C, Kleinewietfeld M, Kunder S, Hafler DA, Sobel RA, Regev A, Kuchroo VK (2012) Induction and molecular signature of pathogenic TH17 cells. Nat Immunol 13:991-999. CrossRef Medline

Lee Y, Collins M, Kuchroo VK (2014) Unexpected targets and triggers of autoimmunity. J Clin Immunol 34:S56-S60. Medline

Lewkowicz P, Cwiklińska H, Mycko MP, Cichalewska M, Domowicz M, Lewkowicz N, Jurewicz A, Selmaj KW (2015) Dysregulated RNAinduced silencing complex (RISC) assembly within CNS corresponds with abnormal miRNA expression during autoimmune demyelination. J Neurosci 35:7521-7537. CrossRef Medline

Loeb GB, Khan AA, Canner D, Hiatt JB, Shendure J, Darnell RB, Leslie CS, Rudensky AY (2012) Transcriptome-wide miR-155 binding map reveals widespread noncanonical microRNA targeting. Mol Cell 48:760770. CrossRef Medline

Lu LF, Thai TH, Calado DP, Chaudhry A, Kubo M, Tanaka K, Loeb GB, Lee H, Yoshimura A, Rajewsky K, Rudensky AY (2009) Foxp3-dependent microRNA 155 confers competitive fitness to regulatory T cells by targeting SOCS1 protein. Immunity 30:80-91. CrossRef Medline

Mansilla MJ, Costa C, Eixarch H, Tepavcevic V, Castillo M, Martin R, Lubetzki C, Aigrot MS, Montalban X, Espejo C (2014) Hsp70 regulates immune response in experimental autoimmune encephalomyelitis. PLoS One 9:e105737. CrossRef Medline

Meijer HA, Smith EM, Bushell M (2014) Regulation of miRNA strand selection: follow the leader? Biochem Soc Trans 42:1135-1140. CrossRef Medline

Murugaiyan G, Beynon V, Mittal A, Joller N, Weiner HL (2011) Silencing microRNA-155 ameliorates experimental autoimmune encephalomyelitis. J Immunol 187:2213-2221. CrossRef Medline

Mycko MP, Cwiklinska H, Szymanski J, Szymanska B, Kudla G, Kilianek L, Odyniec A, Brosnan CF, Selmaj KW (2004) Inducible heat shock protein 70 promotes myelin autoantigen presentation by the HLA class II. J Immunol 172:202-213. CrossRef Medline

Mycko MP, Cwiklinska H, Walczak A, Libert C, Raine CS, Selmaj KW (2008) A heat shock protein gene (Hsp70.1) is critically involved in the generation of the immune response to myelin antigen. Eur J Immunol 38:19992013. CrossRef Medline 
Mycko MP, Cichalewska M, Machlanska A, Cwiklinska H, Mariasiewicz M, Selmaj KW (2012) MicroRNA-301a regulation of a T-helper $17 \mathrm{im}$ mune response controls autoimmune demyelination. Proc Natl Acad Sci U S A 109:E1248-E1257. CrossRef Medline

O’Connell RM, Kahn D, Gibson WS, Round JL, Scholz RL, Chaudhuri AA, Kahn ME, Rao DS, Baltimore D (2010) MicroRNA-155 promotes autoimmune inflammation by enhancing inflammatory $\mathrm{T}$ cell development. Immunity 33:607-619. CrossRef Medline

Oertli M, Engler DB, Kohler E, Koch M, Meyer TF, Müller A (2011) MicroRNA-155 is essential for the T cell-mediated control of Helicobacter pylori infection and for the induction of chronic gastritis and colitis. J Immunol 187:3578-3586. CrossRef Medline

Rauch JN, Gestwicki JE (2014) Binding of human nucleotide exchange factors to heat shock protein 70 (Hsp70) generates functionally distinct complexes in vitro. J Biol Chem 289:1402-1414. CrossRef Medline

Ro S, Park C, Young D, Sanders KM, Yan W (2007) Tissue-dependent paired expression of miRNAs. Nucleic Acids Res 35:5944-5953. CrossRef Medline

Rodriguez A, Vigorito E, Clare S, Warren MV, Couttet P, Soond DR, van Dongen S, Grocock RJ, Das PP, Miska EA, Vetrie D, Okkenhaug K, Enright AJ, Dougan G, Turner M, Bradley A (2007) Requirement of bic/
microRNA-155 for normal immune function. Science 316:608-611. CrossRef Medline

Selbach M, Schwanhäusser B, Thierfelder N, Fang Z, Khanin R, Rajewsky N (2008) Widespread changes in protein synthesis induced by microRNAs. Nature 455:58-63. CrossRef Medline

Sospedra M, Martin R (2005) Immunology of multiple sclerosis. Annu Rev Immunol 23:683-747. CrossRef Medline

Tarassishin L, Loudig O, Bauman A, Shafit-Zagardo B, Suh HS, Lee SC (2011) Interferon regulatory factor 3 inhibits astrocyte inflammatory gene expression through suppression of the proinflammatory miR-155 and miR-155*. Glia 59:1911-1922. CrossRef Medline

Wang Y, Juranek S, Li H, Sheng G, Wardle GS, Tuschl T, Patel DJ (2009) Nucleation, propagation and cleavage of target RNAs in Ago silencing complexes. Nature 461:754-761. CrossRef Medline

Xiao C, Rajewsky K (2009) MicroRNA control in the immune system: basic principles. Cell 136:26-36. CrossRef Medline

Zhou H, Huang X, Cui H, Luo X, Tang Y, Chen S, Wu L, Shen N (2010) miR-155 and its star-form partner miR-155* cooperatively regulate type I interferon production by human plasmacytoid dendritic cells. Blood 116: 5885-5894. CrossRef Medline 